\title{
PERAN AKTIF HAKIM DALAM PEMERIKSAAN KETERANGAN SAKSI DALAM PERSIDANGAN MENUJU HAKIM YANG PROFESIONAL DI ERA KEMAJUAN TEKHNOLOGI INFORMASI
}

\author{
Uswatul Fikriyah \\ Pengadilan Agama Sulawesi Utara \\ Anaa.uswah@gmail.com
}

\begin{abstract}
Abstrak:
Dalam perkara perdata di Pengadilan Agama khususnya perceraian alat bukti saksi adalah hal yang banyak dihadirkan oleh para pihak. Hakim harus mempunyai metode dan kemampuan professional untuk menggali fakta hukum dan menghasilkan putusan yang berkualitas, adanya perkembangan tekhnologi informasi yang direspon oleh Mahkamah Agung menjadikan semua proses persidangan dilaksanakan melalui media elektronik. Dalam tulisan ini penulis membahas bagaimana tugas dan peran aktif Hakim dalam memeriksa Keterangan Saksi menuju Hakim yang Profesional di era kemajuan tekhnologi informasi. Hasil dari penelitian ini: seorang hakim dalam menyelesaikan perkara melalui beberapa tahapan yang terdiri dari Konstantir, Kualifisir, dan Konstituir. Dalam setiap tahapan yang dilakukan Hakim harus memunyai kepekaan nurani, mempunyai kecerdasan moral dan mengasah profesionalisme. Profesionalisme seorang hakim harus mengacu pada Poin 10 kode etik dan pedoman perilaku hakim. terkait professional, hakim dimaknai sebagai suatu sikap moral yang dilandasi oleh tekad untuk melaksanakan tugasnya dengan kesungguhan yang didukung oleh keahlian, ketrampilan, dan wawasan luas. Selain itu Hakim juga harus berpedoman pada konsep profesionalitas dalam Islam lebih dilihat sebagai sinkronisasi antara gerak manusia dalam dua wujud, yaitu rohaniah dan jasmani.
\end{abstract}

Kata Kunci: Peran Hakim, Profesional, Tekhnologi Informasi

\section{Abstract}

In civil cases in the Religious Courts, especially divorce cases, the witnesses evidence is a matter that is always presented by the parties. Judges must have professional methods and abilities to explore legal facts and produce quality decisions, the development of information technology that was responded by the Supreme Court made all proceedings carried out through electronic media. In this paper discusses how the duties and the roles of Judges in examining the Witness' statements to become Professional Judges in the era of advancement in information technology. The results of this study: a judge in deciding a case through several stages consisting of Constantine, Qualifiers, and Constituencies. In each stage, the Judge must have a sensitivity of conscience, moral intelligence and hone professionalism. Professionalism of judges must refer to Point 10 of the ethics code and guidelines for judge behavior. Professionalism of judge is interpreted as a moral attitude based on a determination to carry out the task seriously supported by expertise, skills, and broad insight. In addition, the Judge must be guided by the concept of islamic professionalism, which is seen as a synchronization between buman movements in two forms, namely spiritual and physical.

Keywords: Role of Judges, Professional, Information Technology

\section{PENDAHULUAN}

Pasal 1 UU No. 4 Tahun 2004 menyebutkan: "Kekuasaan kehakiman adalah kekuasaan negara yang merdeka untuk menyelenggarakan peradilan guna menegakkan hukum dan keadilan berdasarkan Pancasila, demi terselenggaranya Negara hukum Republik Indonesia". Hakim bertugas

DOI: https://doi.org/10.35719/aladalah.v22i2.19 
untuk mengambil keputusan atas sengketa yang diajukan kepadanya melalui proses pemeriksaan yang dilakukan dalam persidangan. Hakim berkewajiban untuk dapat mengolah dan memproses data- data yang diperoleh selama proses persidangan baik yang berasal dari bukti surat, saksi, persangkaan, pengakuan maupun sumpah yang terungkap dalam persidangan. Sehingga dalam setiap putusan yang akan dijatuhkan harus didasari oleh rasa tanggungjawab, keadilan, kebijaksanaan, profesionalisme dan bersifat obyektif.

Dalam memutus perkara Hakim harus mengacu kepada fakta yang terungkap di dalam persidangan. Untuk itu hakim harus menggali nilai- nilai, mengikuti dan memahami nilai- nilai hukum dan rasa keadilan yang hidup dalam masyarakat. ${ }^{1}$ Sumber hukum yang dapat diterapkan oleh hakim dapat berupa peraturan perundang- undangan berikut peraturan pelaksanaannya, hukum tidak tertulis (hukum adat), yurisprudensi, ilmu pengetahuan maupun doktrin/ ajaran para ahli. $^{2}$

Dalam perkara perdata di Pengadilan Agama khususnya perceraian alat bukti saksi menjadi alat bukti yang banyak dihadirkan oleh para pihak. Untuk dapat menggali fakta hukum dari keterangan saksi ini hakim harus mempunyai metode dan kemampuan yang professional untuk dapat menggali fakta hukum guna menghasilkan produk putusan yang berkualitas lebih- lebih lagi dengan adanya perkembangan tekhnologi informasi yang direspon oleh Mahkamah Agung dengan adanya pelaksanaan e-litigasi sehingga semua proses persidangan diupayakan untuk dilaksanakan melalui media elektronik. Dalam tulisan ini penulis mencoba untuk membahas bagaimana tugasdan peran aktif Hakim dalam Pemeriksaan Keterangan Saksi dalam Persidangan menuju Hakim yang Profesional di era kemajuan tekhnologi informasi.

\section{PEMBAHASAN}

\section{Tugas dan Profesionalitas Hakim dalam Pemeriksaan Perkara}

Hakim dalam melaksanakan proses pemeriksaan perkara di Pengadilan dengan melalui beberapa tahapan. Yang pertama tahap konstantir yaitu hakim harus melihat, mengakui dan membenarkan telah terbuktinya peristiwa- peristiwa yang bersangkutan telah benar- benar terjadi. Kemudian peristiwa- peristiwa yang telah dikonstantirnya sebagai peristiwa yang telah benar- benar terjadi kemudian harus dikualifisir. ${ }^{3}$ sehingga kualifisir dapat diartikan sebagai menilai peristiwa yang telah dianggap benar- benar terjadi dengan cara memilih kejadian- kejadian atau peristiwaperistiwa hukum dari hasil pemeriksaan di persidangan dan selanjutnya hasil penilaian peristiwa hukum tersebut dihubungkan dengan norma hukumnya. ${ }^{4}$

Menurut Prof. Dr. Sudikno Mertokusumo, S.H., mengkualifisir berarti menilai peristiwa yang telah dianggap benar-benar terjadi itu termasuk hubungan hukum apa atau yang mana, dengan perkataan lain menemukan hukumnya bagi peristiwa yang telah dikonstatir. ${ }^{5}$

Mengkualifisir peristiwa jauh lebih sukar daripada mengkonstatir peristiwa, karena mengkonstatir peristiwa berarti melihat peristiwa konkrit, sesuatu yang dapat dilihat, sedangkan kualifikasi dalam hal ini abstraksi dari pada peristiwa konkrit tersebut. Mengkualifisir pada hakekatnya tidak lain daripada menilai, dan menilai merupakan pertimbangan yang tidak sematamata logis sifatnya seperti dalam hal mengkonstatir peristiwa. Mengkualifisir peristiwa mengandung unsur kreatif seperti yang telah dikemukakan di atas dan ini sekaligus berarti juga melengkapi undang- undang. ${ }^{6}$

\footnotetext{
${ }^{1}$ Pasal 5 Undang- Undang Nomor 48 Tahun 2009 Tentang Kekuasaan Kehakiman

${ }^{2}$ R. Soeparmono, Hukum Acara Perdata dan Yurisprudensi, (Bandung: Mandar Maju, 2005), 146

3 Sudikno Mertokusumo, Hukum Acara Perdata Indonesia, (Yogyakarta: Penerbit Liberty. 2009), 93.

${ }^{4}$ Achmad Ali, Menguak Tabir Hukum, (Bogor: Penerbit Ghalia Indonesia, 2015), 120

5 Achmad Ali,, Menguak Tabir Hukum, 120

${ }^{6}$ Sudikno Mertokusumo, S.H., Hukum Acara Perdata Indonesia, 96
} 
Untuk menemukan hukumnya atau undang-undangnya agar diterapkan pada peristiwa konkrit, peristiwa konkrit itu harus diarahkan kepada undang-undangnya, sebaliknya undangundang harus disesuaikan dengan peristiwa konkrit. ${ }^{7}$ Sehingga pada tahap mengkualifisir, maka hakim akan melahirkan peristiwa konkrit, dan hakim pada tahapan ini memulai daya kreatifnya untuk menemukan hukum- hukumnya dari peristiwa-peristiwa konkrit yang terungkap dalam persidangan. Selanjunya tahapan terakhir oleh hakim dalam membuat produk putusan adalah konstituir yakni menerapkan hukum (premis mayor) dari peristiwa konkrit tersebut.

Secara ringkas tahapan tugas hakim tersebut adalah sebagai berikut:

a. Tahap konstatir, Konstatir berarti melihat, mengakui atau membenarkan telah terjadi peristiwa yang telah diajukan tersebut.

b. Tahap kualifisir, Kualifisir berarti menilai peristiwa yang telah dianggap benar-benar terjadi itu termasuk hubungan hukum apa atau yang mana, dengan perkataan lain menemukan hukumnya bagi peristiwa yang telah dikonstatir.

c. Tahap konstituir,

d. dalam tahap terakhir, sesudah mengkonstatir dan mengkualifisir, hakim harus mengkonstituir atau memberi kontitusinya (putusan).

Hakim sebagai sosok sentral dalam proses pemeriksaan perkara di Pengadilan senantiasa dituntut untuk dapat memunyai kepekaan nurani, mempunyai kecerdasan moral dan terus mengasah profesionalisme dalam penegakan hukum dan keadilan bagi masyarakat pencari keadilan. Selain itu Hakim dalam menjalankan tugasnya dituntut untuk memiliki kemampuan professional dan mempunyai integritas tinggi.

Prfesionalitas merupakan sebuah kemampuan untuk bertindak secara professional. ${ }^{8}$ Tindakan professional akan selalu dikaitkan dengan profesi, dan seorang pengemban profesi dikatakan sebagai professional manakala dirinya memiliki keahlian di bidang tertentu dari suatu golongan profesi tersebut. Hubungan antara profesionalits, professional dan profesionalisme yang dapat disimpulkan adalah diperlukannya profesionalitas dalam sifat professional sebagai katalisator untuk sampai pada titik profesionalisme yang baik.

Profesionanilsme seringkali digunakan untuk menakar sebuah nilai- nilai dari kompetensi, kesopanan dan karakter dan komitmen atas kepentingan public. ${ }^{9}$ Cmibridge Dictionary menjabarkan konsep profesionalsme sebagai kombinasi dari segala kualitas yang terhubung dengan orang yang terlatih dan memiliki keahlian. Sedangkan menurut Oxford Dictionary, profesionalisme dimaknai sebagai kompetensi atau keahlian yang diharapkan dari seorang professional. ${ }^{1}$

Penerapan sifat profesional yang dijabarkan lebih detail dalam KEPPH yaitu: ${ }^{1}$

1. Hakim harus mengambil langkah- langkah untuk memelihara dan meningkatkan pengetahuan, ketrampilan dan kualitas pribadi untuk dapat melaksanakan tugas- tugas peradilan secara baik.

2. Hakim harus secara tekun melaksanakan tanggung jawab administrative dan bekerja sama dengan para Hakim dan pejabat pengadilan lain dalam menjalankan administrasi peradilan.

7.Abdul Manan, Penerapan Hukum Acara Perdata di Lingkungan Peradilan Agama, (Jakarta: Penerbit Kencana, 2012), 288

8https://kbbi.web.id/profesionalitas, diakses pada hari senin 25 November 2019 pukul $19.00 \mathrm{WIB}$

${ }^{9}$ Measuring Professionalism, State Bar of Georgia,

https://www.gabar.org/aboutthebar/lawrelatedorganizations/cjcp/measuring-professionalism.cfm, diakses pada hari senin, 25 November 2019 pukul $20.00 \mathrm{WIB}$

1 Oxford Dictionary, https://erf.oxforddictionaries.com/definition/professionalism, diakses pada hari selasa, 26 November 2019 pukul 09.00 WIB

1 Poin ke-sepuluh Kode Etik dah Pedoman Perilaku Hakim 
3. Hakim wajib mengutamakan mengutamakan tugas yudisialnya di atas kegiatan yang lain secara professional.

4. Hakim wajib menghindari terjadinya kekeliruan dalam membuat keputusan atau mengabaikan fakta yang dapat menjerat terdakwa atau para pihak atau dengan sengaja membuat pertimbangan yang menguntungkan terdakwa atau para pihak dalam mengadili suatu perkara yang ditanganinya.

Di dalam penjabaran Kode Etik dan Pedoman Perilaku Hakim (KEPPH) terkait professional bagi profesi hakim dimaknai sebagai suatu sikap moral yang dilandasi oleh tekad untuk melaksanakan pekerjaan yang dipilihnya dengan kesungguhan yang didukung oleh keahlian atas dasar pengetahuan, keterampilan, dan wawasan luas. Lebih lanjut bahwa seseorang dengan sikap professional akan senantiasa menciptakan, menjaga dan mempertahankan mutu pekerjaan sehingga dirinya akan selalu memperbaharui tingkatan pengetahuan dan kinerjanya. ${ }^{1}$

Menurut paradigma professional sebagai sebuah nilai, setidaknya terdapat 5 poin dasar yang dapat menggambarkannya, yaitu:

a. Sifat dapat dipercaya dan mementingkan orang lain (trustworthiness and altruism)

b. Akuntabilitas (accountability)

c. Netralitas dan kredibilitas (impartiality and credibility)

d. Transparansi (transparency), serta

e. Integritas dan kejujuran (integrity and honesty)

Profesionalitas seorang hakim dalam konsep Islam berkaitan dengan etika Islam. Etika Islam merupakan suatu sistem akhlak yang berbasis pada kepercayaan kepada Allah SWT dengan berlandaskan kepada agama Islam. Etika profesi Hakim sendiri merupakan salah satu bagian kecil dalam sistem akhlak tersebut. Akan tetapi etika Islam tidak sampai pada pembahasan yang detail yang menjabarkan etika profesi sebagai applied ethics atau bersifat baku. Dalam Islam terdapat empat cerminan kata sifat untuk menggambarkan etika profesi dalam Islam yang juga bisa diterapkan bagi seorang hakim yaitu diantaranya sifat istiqamah, fathanah, amahah dan tabligh. ${ }^{1}$

Konsep profesionalitas dalam Islam lebih dilihat sebagai sinkronisasi antara gerak manusia dalam dua wujud, yaitu rohaniah dan jasmani. Islam memberikan standar bahwa profesionalitas seorang muslim adalah ditunaikannya segala bentuk amanah yang telah dibebankan kepada seseorang dengan Ikhlas hanya untuk mendapatkan Ridha Allah SWT. Usaha melaksanan amanah itu sendiri dilakukan secara berkelanjutan dengan usaha perbaikan yang terus meners karna pengawasan Allah SWT. ${ }^{1}$ Sehingga dalam Islam ${ }^{4}$ terdapat tiga aspek utama yang mendasari profesionalitas yaitu Iman, Islam dan Ihsan.

Dalam menjalankan tugasnya pada pemeriksaan perkara hakim harus senantiasa mengacu pada konsep dan prinsip profesionalitas hakim yang mengacu pada Kode Etik dan Pedoman Peilaku Hakim serta konsep profesionalitas dalam Islam.

\section{Peran Aktif Hakim dan Metode dalam Menggali Keterangan Saksi di persidangan}

Diantara tugas hakim dalam menyelesaikan perkara perdata adalah menggali apakah hubungan hukum yang menjadi dasar adanya gugatan ke Pengadilan Agama itu benar- benar ada atau tidak. Untuk dapat mengetahui hal tersebut hakim harus mencari kebenaran peristiwa yang bersangkutan secara objektif melalui proses pembuktian di pesidangan. Dalam hal ini proses

1 Poin ke-sepuluh Kode Etik dån Pedoman Perilaku Hakim di dalam Keputusan Bersama Ketua Mahkamah Agung RI dan Ketua Komisi Yudisial RI Nomor 047/KMA/SKB/IV/2009, 02/SKB/P.KY/IV/2009 tentang Kode Etik dan Pedoman Perilaku Hakim

1 Sahmiar Pulungan, "Etos Kerja³dan Etika Profesi dalam Pandangan Islam", Jurnal Wahana Inovasi, Universitas Islam Sumatera Utara, Vol. 3 No.2, Juli-Desember 2014, 516

${ }^{1}$ Mohammad Ghozali dan Nor ${ }^{4}$ Azzah Kamri, "Kepribadian Islam dan Profesionalisme dalam Pekerjaan: Satu Analisis Teoritis”, Jurnal Syariah, Vol. 23 No. 2, 2015, lm. 270. 
pembuktian di persidangan bertujuan untk memperoleh kebenaran suatu peristiwa sehingga dapat ditetapkan hubungan hukum antara kedua pihak yang berperkara dan menetapkan bagaimana rumusan putusan yang dapat dijatuhkan oleh hakim berdasarkan hasil dari proses pembuktian.

Mengenai alat bukti yang diakui di dalam hukum acara perdata diatur secara enumerative dalam Pasal 1866 KUH Perdata pada Pasal 164 HIR dimana alat bukti tersebut terdiri dari: 1) bukti tulisan (surat), 2) bukti dengan saksi, 3) persangkaan, 4) pengakuan dan 5) sumpah.

Dalam proses pembuktian, hakim bertugas untuk membagi beban pembuktian, menilai apakah dapat atau tidaknya suatu alat bukti diterima serta menilai akan kekuatan alat bukti yang diajukan. Hakim dalam proses pembuktian terikat pada alat bukti yang sah berdasarkan peraturan perundang yang diajukan oleh para pihak dalam persidangan. Dalam perkara perdata keyakinan hakim bukanlah merupakan hal yang esensial dalam menentukan kebenaran suatu peristiwa. Hal ini berbeda dengan hukum acara pidana yang menentukan bahwa selain berdasarkan alat- alat bukti yang sah sesuai peraturan perundangan, keyakinan hakim mutlak diperlukan untuk menentukan apakah terdakwa memang bersalah dan dapat dipertanggungjawabkan secara pidana. Di dalam tradisi hukum Anglo Saxon seperti di Inggris, perbedaan antara perkara perdata dan pidana ini disebut dengan terminology yang berbeda, yaitu preponderance of evidence dan beyond reasonable doubt. Sehingga telah popular bahwa peradilan perdata mencari kebenaran formil sedangkan dalan peradilan pidana mencari kebenaran materiil.

Dalam hukum acara perdata yang berlaku belakangan ini adalah prinsip yang dianut bukanlah hakim pasif, hal ini didasarkan kepada Herzeine Indonesisch Reglement (H.I.R). Dalam prinsip hakim aktif dalam perkara perdata berlaku pameo secundum allegat indicare. Sebagaimana dikemukakan oleh M. Yahya Harahap bahwa situasi ini sebagai suatu gejala munculnya aliran baru dalam ranah hukum acara perdata yang mncoba untuk berbeda dengan gagasan hakim bersifat pasif total dengan berusaha mempekenalkan prinsip hakim aktif argumentative. Sama halnya ini terlihat di dalam pertentangan antara secara teoritis prinsip hakim pasif adalah prinsip yang dianut (R.v) sementara di dalam praktiknya prinsip hakim aktif adalah yang dipakai (H.I.R).

Dikarenakan dalam perkara perdata terdapat adagium bahwa kebenaran yang dicari adalah kebenaran formil maka saksi merupakan alat bukti pelengkap dari pembuktian di dalam peradilan perdata. Alasan yang menyebabkan alat bukti saksi bukan alat bukti utama dalam hukum acara perdata adalah alat bukti saksi mempunyai keterbatasan seperti ingatan manusia yang terbatas dan sifat mudah lupa serta adanya keterbatasan waktu yang dimiliki oleh manusia.

Sebagai suatu alat bukti yang bukan bersifat utama, maka kekuatan pembuktian dengan saksi bersifat bebas. Sebagaimana dikemukakan oleh Mukti Arto yaitu apabila saksi telah memenuhi syarat formil dan materiil, maka ia akan memiliki nilai pembuktian yang bebas sehingga hakim bebas untuk menilai kesaksian itu sesuai dengan hati nuaninya. ${ }^{1}$

Di dalam ketentuan Pasal 150 HIR disebutkan bahwa hakim mempunyai wewenang untuk memimpin jalannya pemeriksaan terhadap saksi. Ayat (3) pasal tersebut menyatakan bahwa atas kemauannya sendiri haim boleh mengajukan pertanyaan kepada saksi dalam rangka mencapai kebenaran. Aturan ini menegaskan mengenai peran aktif hakim dalam memimpin persidangan khususnya pada saat pemeriksaan saksi sebagai bagian dari tahap pembuktian.

Secara umum tata cara pemeriksaan saksi diatur di dalam Pasal 150, 151, dan 152 HIR. Sedangkan tata cara pemeriksaan saksi dapat dilakukan dengan beberapa metode yaitu : ${ }^{1}$

1. Memberi hak kepada para pihak mengajukan pertanyaan kepada setiap saksi yang diajukan dalam persidangan sesuai dengen ketentuan Pasal 150 ayat (1) HIR bahwa kedua pihak yang berperkara dapat mengajukan pertanyaan kepada saksi, yang dibedakan menjadi 2 metode yaitu:

1 Mukti Arto, Praktek Perkara Perdata, (Yogyakarta: Pustaka Pelajar. 2008), 62

1 Yahya Harahap, Hukum Acar' Perdata, (Jakarta: Sinar Grafika, 2017), 215 
a. Pihak yang mengajukan saksi lebih dahulu bertanya. Hal ini sesuai dengan tujuan mengajukan saksi di persidangan yang tiada lain untuk membuktikan kebenaran dalil gugatan atau dalil bantahan pihak yang menghadirkan saksi.

b. Pemeriksaan Silang (Cross Examination). Dimana metode ini bertujuan untuk memberi kesempatan kepada pihak lawan untuk menguji keakurasian keterangan yang diberikan saksi pada pemeriksaan sebelumnya. Kesempatan untuk melakukan pemeriksaan silang kepada saksi baru diberikan kepada pihak lawan setelah pihak yang menghadirkan saksi selesai mengajukan pertanyaan.

c. Pertanyaan disampaikan melalui Ketua Majelis. Berdasarkan Pasal 150 ayat (1) menegaskan bahwa pertanyaan saksi melalui Ketua Majelis. hal ini sesuai dengan fungsi hakim yaitu memimpin jalannya persidangan dan sekaligus untuk menjaga dan menegakkan tata tertib persidangan. Dalam mekanismenya tidak harus semua pertanyaan perlu disampaikan melalui Ketua Majelis, namun para pihak dapat diberi izin untuk melangsungkan Tanya - jawab di bawah arahan dan pengawasan Ketua Majelis.

2. Hakim berwenang menganulir pertanyaan. Hal ini sesuai dengan ketentuan Pasal 150 ayat (2) HIR yang memberi wewenang kepada hakim untuk menganulir atau menolak pertanyaan yang diajukan untk mengjindari terjadinya proses Tanya- jawab yang berteletele dan menyimpang dari materi pokok perkara.

3. Hakim dapat mengajukan pertanyaan. Berdasarkan pasal 150 ayat (2) HIR memberi hak dan wewenang kepada hakim mengajukan pertanyaan kepada saksi. Berdasarkan pasal ini, sistem partai (adversarial sistem) yang dianut tidak mutlak peranan para pihak semata- mata dalam pemeriksaan saksi tetapi memberi hak kepada hakim untuk ikut ambil bagian mencari dan menemukan kebenaran formil melalui keterangan saksi sehingga Hakim aktif dalam pemeriksaan saksi di persidangan bukan pasif mrnonton karena undang- undang memberi wewenang kepadanya mengajukan pertanyaan kepada saksi. Meskipun hakim dapat mengajukan pertanyaan kepada saksi namun berdasarkan akhir kalimat Pasal 150 ayat (3) HIR hakim tidak boleh mengajukan pertanyaan di luar lingkup dari perkara.

Dalam praktik, metode yang lebih sering digunakan dalam pemeriksaan saksi di pengadilan Agama adalah dengan Hakim aktif mengajukan pertanyaan kepada saksi yang dihadirkan oleh para pihak sesuai dengan pokok perkara dan kemudian dipadukan dengan metode cross examination setelah Majelis Hakim selesai memberikan pertanyaan Majelis Hakim memberikan kesempatan kepada pihak untuk memberikan pertanyaan kepada saksi dengan izin Ketua Majelis. Metode ini lebih sering digunakan karena hakim lebih mudah untuk mengatur dan mengontrol jalannya persidangan agar berjalan lancar dan tidak keluar dari konteks pokok perkara.

Dalam mengggali fakta hukum melalui proses pemeriksaan saksi di persidangan, hakim harus meemperhatikan pertanyan- pertanyaan yang diajukan agar memenuhi semua unsur pertanyaan yang efektif yaitu terdiri dari $5 \mathrm{~W}$ dan IH yaitu What, Who, Why, When, Where dan How. Dengan tercakupnya unsur pertanyaan ini maka akan ditemukan fakta mengenai apa yang benar- benar terjadi. Selain itu dalam mengajukan pertanyaan- pertanyaan kepada saksi Hakim tidak boleh mengajukan pertanyaan yang sifatnya menjebak atau menggiring saksi untuk pada jawaban tertentu sehingga saksi akan menyampaikan apa yang benar- benar ia ketahui.

Selain memperhatikan pertanyaan yang memenuhi $5 \mathrm{~W}$ dan $1 \mathrm{H}$, Hakim dalam memberikan pertanyaan kepada saksi juga harus memperhatikan dan menggunakan bahasa lugas, sederhana dan dapat dengan mudah dimengerti oleh saksi. Memang menjadi sebuah permasalahan dimana terkadang saksi yang dihadirkan oleh pihak hanya dapat berbicara dengan bahasa daerah sehingga tidak begitu memahami pertanyaan- pertantaan yang diberikan oleh hakim sehingga keterangan yang diberikan oleh saksi pun tidak relevan dengan pokok perkara. Namun atas kesulitan ini 
sebenarnya dapat diatasi dengan adanya jasa penerjemah yang menghubungkan komunikasi Tanya jawab antara hakim dan saksi dalam pemeriksaan keterangan saksi di persidangan.

\section{Keabsahan Teleconference dalam Pemeriksaan Saksi}

Dalam menghadapi era Tekhnologi informasi yang semakin pesat, perubahan mutlak akan terjadi. Sebagaimana Heraclictus yang mengatakan bahwa perubahan adalah keniscayaan "nothing endures but change" (tidak ada yang tidak berubah, kecuali perubahan itu sendiri). Hal ini juga beraku pada zaman yang akan terus berkembang dan berubah sehingga pada akhirnya hukum acara yang berstigma rigid dan kaku akan berjumpa dengan perubahan zaman dan pada akhirnya akan menjadi lentur mengikuti perubahan zaman.

Mengenai pemeriksana saksi secara elektronik, nampaknya Hukum Acara Pidana terlihat lebih cepat terhadap perkembangan IT tersebut. Hal ini terbukti di dalam hukum acara pidana, pada kondisi- kondisi tertentu telah terdapat aturan yang mengakomodir kebolehan pemeriksaan saksi dengan tidak dihadirkan langsung di muka persidangan, akan tetapi diperiksa dengan menggunakan sarana elektronik. Diantara aturan tersbeut adalah sebagai berikut:

1. Pasal 33 dan Pasal 34 ayat (1) huruf c Peraturan Pemerintah Pengganti Undang-Undang Nomor 1 tahun 2002 tentang Pemberantasan Tindak Pidana Terorisme, yang mana Perpu tersebut telah ditetapkan sebagai undang-undang oleh UndangUndang Nomor 15 tahun 2003 tentang Penetapan Peraturan Pemerintah Pengganti Undang-Undang Nomor 1 tahun 2002 tentang Pemberantasan Tindak Pidana Terorisme menjadi UndangUndang

2. Pasal 2 dan Pasal 3 huruf c Peraturan Pemerintah No. 24 tahun 2003 tentang Tata Cara Perlindungan terhadap saksi, Penyidik, Penuntut Umum, dan Hakim dalam Perkara Tindak Pidana Terorisme;

3. Pasal 9 ayat (1) dan ayat (3) Undang-Undang No. 13 tahun 2006 tentang Perlindungan Saksi dan Korban

Sedangkan jika kita melihat pada hukum acara perdata, belum ada peraturan yang mengakomodir mengnai sah atau tidaknya pemeriksaan saksi melalui sarana tekhnologi informasi sehingga akibat dari tidak ada aturan yang jelas ini maka timbulah pro kontra terkait sah atau tidaknya pemeriksaan saksi melalui media elektronik salah satunya teleconference.

Merespon perkembangan tekhnologi yang semakin pesat, Hukum acara perdata salah satunya dengan keabsahan pangilan sidang melalui media elektronik yang berdasarkan pada:

1. Pasal 8 angka 3 Peraturan Mahkamah Agung Nomor 14 tahun 2016 tentang Tata Cara Penyelesaian Perkara Ekonomi Syari'ah menyatakan "pemanggilan lanjutan atas kesepakatan para pihak dapat dilakukan dengan bantuan teknologi informasi".

2. Surat Edaran Nomor 1 tahun 2017 Tentang Pemberlakuan Hasil Rapat Pleno Kamar Mahkamah Agung Tahun 2017 Sebagai Pedoman Pelaksanaan Tugas Bagi Pengadilan, poin 5.b menyatakan "panggilan kedua dan selanjutnya dapat dilaksanakan sesuai dengan ketentuan peraturan Mahkamah Agung Nomor 14 tahun 2016 tentang Tata Cara Penyelesaian Perkara Ekonomi Syari'ah"

Perlu pula kita menyadari bahwa hukum acara bukanlah suatu firman sakral yang tidak dapat diubah namun juga tidak semudah itu pula dapat disimpangi atau diabaikan. Namun dikarenakan hukum acara merupakan perangkat untuk menegakkan hukum materiil, maka hukum acara harus diletakkan secara presisi pada tempatnya. Sehingga dalam menghadapi perubahan zaman jika dikehendaki hukum acara perdata dapat berubah namun tetap harus diorientasikan untuk menegakkan hukum materiil dan dilakukan dengan metode yang tentunya dapat dipertanggungjawabkan.

Terhadap pemeriksaan saksi secara elektronik atau dengan teleconference, Hakim dapat menggunakan metode analogi. Dimana hakim dalam konteks ini adalah membentuk hukum 
terhadap suat peristiwa in concreto yang belum ada pengaturannya dengan keadaan (circumstances) yang mirip dengan peristiwa hukum lain yang telah diatur aturan perundangan.

Terdapat beberapa syarat formil dalam pemeriksaan saksi: 1) memberikan keterangan di depan sidang pengadilan, 2) bukan orang yang dilarang untuk didengar sebagai saksi, 3) bagi kelompok yang berhak mengundurkan diri menyatakan kesediaannya untuk diperiksa sebagai saksi dan 4) mengucapkan sumpah menurut agama yang dianutnya.

Saksi harus memberikan keterangan di depan sidang pengadilan sebagaimana telah diatur secara tegas di dalam HIR dan RBg yaitu sebagai berikut:

1. Pasal 144 HIR: "Saksi yang menghadap pada hari yang ditentukan itu dipanggil ke dalam seorang demi seorang..."

2. Pasal 171 (1) RBg: "Saksi - saksi yang telah datang menghadap, dipanggil satu per satu untuk masuk ruangan sidang".

Akan tetapi melihat pada syarat formil pemeriksaan saksi yang tertuang di dalam HIR dan RBg tersebut, perlu pula kiranya kita melihat pada ketentuan lain diantaranya:

1. Pasal 1927 KUH Perdata: "Suatu pegakuan lisan yang diberikan di luar sidang pengadilan tidak dapat diguakan untuk pembuktian, kecuali dalam hal pembuktian dengan saksi- saksi diizinkan". Sehingga melihat pada pasal ini, dalam keadaan tertentu seperti sakit atau hal lain saksi dapat diperiksa di luar sidang pengadilan. Dengan adanya pasal ini hukum acara perdata secara tidak langsung memberikan peluang bagi pemeriksaan saksi yang berada di luar ruang persidangan.

Untuk dapat menganalogikan pemeriksaan saksi secara elektronik/ teleconference, kita dapat melihat respon hukum acara perdata dalam menerima arus perkembangan tekhnologi yaitu melalui:

1. Pasal 8 angka 3 Peraturan Mahkamah Agung Nomor 14 Tahun 2016 tentang Tata Cara Penyelesaian Perkara Ekonomi Syariah menyatakan "pemanggilan lanjutan atas kesepakatan para pihak dapat dilakukan dengan bantuan rekhnologi informasi", dan

2. Surat Edaran Nomor 1 tahun 2017 tentang Pemberlakuan Hasil Rapat Pleno Kamar Mahkamah Agung Tahun 2017 Sebagai Pedoman Pelaksanaan Tugas Bagi Pengadilan, poin 5.b menyatakan "panggilan kedua dan selanjutnya dapat dilaksanakan sesuai dengan ketentuan peraturan Mahkamah Agung Nomor 14 tahun 2016 tentang Tata Cara Penyelesaian Perkara Ekonomi Syari'ah."

Mengacu pada dua aturan tersebut terdapat kesamaan dimana panggilan sidang dan pemeriksaan saksi adalah sama- sama menggunakan media tekhnologi yang keduanya mempunyai alasan yaitu merupakan adaptasi hukum acara perdata terhadap perkembangan zaman dan tekhnologi informasi dan terwujudnya kemudahan berperkara sehingga akan terwujud azas peradilan yang sederhana, cepat dan biaya ringan. Sehingga dengan menganalogikan panggilan elektronik dengan pemeriksaan saksi di luar persidangan, maka dapat dikatakan sama keabsahannya dengan adanya syarat adanya kesepakatan dari kedua belah pihak mengenai panggilan secara elektronik dan pemeriksaan saksi secara elektronik dengan media teleconference atau video call. Adanya kesepakatan kedua belah pihak tersebut wajib dituangkan di dalam berita acara sidang.

Dalam menilai keterangan saksi yang diperiksa secara elektronik tidak semua keterangan saksi adalah layak dipercaya dan dapat diterima. Kembali lagi bahwa penilaian ini diserahkan secara bebas kepada keyakinan Hakim sehingga pengalaman dan analisis seorang Hakim merupakan panduan terbaik yang dapat digunakan untuk menentukan mana yang layak atau tidak untuk diterima. 
Sahnya pemeriksaan keterangan saksi dengan memanfaatkan media elektronik dapat dijelaskan melalui beberpa sisi yaitu: ${ }^{1}$

a. Keterangan saksi di muka persidangan. Penggunaan media elektronik seperti teleconference/ video call telah menyajikan gambar secara detail dan kualitas suara yang jelas tanpa gangguan sehingga hakim dapat mengetahui secara langsung sorot mata, roman muka maupun bahasa tubun yang ditunjukan oleh seorang saksi di muka persidangan sebagaimana fisik juga telah terpenuhi dengan media teleconference/ video call tersebut.

b. Dengan sumpah terlebih dahulu. Pemeriksaan saksi melalui media elektronik dilakukan tidak berbeda dengan pemeriksaan saksi di dalam ruang sidang yaitu dengan terlebih dahulu disumpah sebelum saksi memberikan keterangan.

c. Tentang peristiwa tertentu yang ia dengar, ia lihat dan alami sendiri. Keterangan yang diberikan oleh saksi dengan media elektronik yaitu teleconference/video call juga dapat memenuhi unsur tersebut, namun kembali lagi bebas bagi hakim untuk menggunakan kemampuan pengalamannya apakah keterangan yang diberikan dapat diterima atau tidak.

\section{DAFTAR PUSTAKA}

Ali, Achmad. Menguak Tabir Hukum. Bogor: Penerbit Ghalia Indonesia. 2015

Arto, Mukti. Praktek Perkara Perdata. Yogyakarta: Pustaka Pelajar. 2008

Ghozali, Mohammad dan Nor 'Azzah Kamri. "Kepribadian Islam dan Profesionalisme dalam Pekerjaan:

Satu Analisis Teoritis” Jurnal Syariah, Vol. 23 No. 2, 2015

Harahap, Yahya. Hukum Acara Perdata. Jakarta: Sinar Grafika. 2017

Keputusan Bersama Ketua Mahkamah Agung RI dan Ketua Komisi Yudisial RI Nomor

047/KMA/SKB/IV/2009, 02/SKB/P.KY/IV/2009 tentang Kode Etik dan Pedoman

Perilaku Hakim

Manan, Abdul. Penerapan Hukum Acara Perdata di Lingkungan Peradilan Agama. Jakarta: Penerbit

Kencana. 2012

Mertokusumo, Sudikno, Hukum Acara Perdata Indonesia, Yogyakarta: Penerbit Liberty. 2009

Pulungan, Sahmiar. "Etos Kerja dan Etika Profesi dalam Pandangan Islam". Jurnal Wahana Inovasi,

Universitas Islam Sumatera Utara, Vol. 3 No.2, Juli-Desember 2014

Rustamaji, Muhammad. Teleconference Dalam Kacamata Hukum Pembuktian;

Soeparmono, R., Hukum Acara Perdata dan Yurisprudensi. Bandung: Mandar Maju. 2005

Undang- Undang Nomor 48 Tahun 2009 Tentang Kekuasaan Kehakiman

https://kbbi.web.id/profesionalitas

Oxford Dictionary, https://en.oxforddictionaries.com/definition/professionalism

Measuring Professionalism, Bar of Georgia,

https://www.gabar.org/aboutthebar/lawrelatedorganizations/cjcp/measuring-

professionalism.cfm

1 Muhammad Rustamaji, Teleconference Dalam Kacamata Hukum Pembuktian, Data Diakses pad ahari rabu, 27 November 2019 Pukul 11.00 WIB 